\title{
Respon Galur-galur Harapan Padi Sawah Dihaploid terhadap Salinitas pada Fase Bibit
}

\author{
Response of Promising Doubled-Haploid Lowland Rice Lines to Salinity at Seedling Stage
}

\section{Anggita Duhita Anindyajati ${ }^{1}$, Bambang Sapta Purwoko ${ }^{2 *}$, Iswari Saraswati Dewi ${ }^{3}$, dan Willy Bayuardi Suwarno}

${ }^{1}$ Program Studi Pemuliaan dan Bioteknologi Tanaman, Sekolah Pascasarjana, Institut Pertanian Bogor

${ }^{2}$ Departemen Agronomi dan Hortikultura, Fakultas Pertanian, Institut Pertanian Bogor

(IPB University), J1. Meranti, Kampus IPB Darmaga, Bogor 16680, Indonesia

${ }^{3}$ Balai Besar Penelitian dan Pengembangan Bioteknologi dan Sumberdaya Genetik Pertanian

Jl. Tentara Pelajar 3A, Bogor 16111, Indonesia

Diterima 23 Agustus 2021/Disetujui 28 Oktober 2021

\begin{abstract}
Due to climate change, Indonesian rice breeders have recently experienced salt issues. Salinity has been reported in many studies to cause plant growth reduction and severe yield loss in rice. This research aimed at evaluating salinity tolerance of doubled-haploid $(\mathrm{DH})$ lines derived from anther culture at the seedling stage. The research was conducted at ICABIOGRAD's greenhouse using a split-plot randomized complete block design. The main plot was $\mathrm{NaCl}$ concentration $(0 \mathrm{mM}$ and $120 \mathrm{mM})$ and the subplot was rice genotypes consisting of 14 doubled-haploid (DH) lines, four new released varieties (NRV), one tolerant check (Pokkali), and one sensitive check (Inpara 4). Seedlings of each rice genotype were grown hydroponically supplemented with different levels of $\mathrm{NaCl}$. Plant growth and visual injury according to Standard Evaluation System for Rice from IRRI were assessed 14 days after $\mathrm{NaCl}$ addition. The results showed that $120 \mathrm{mM} \mathrm{NaCl} \mathrm{reduced} \mathrm{shoot}$ height, root length, leaf number, tiller number, shoot and root fresh weight, shoot and root dry weight, total fresh and dry weight biomass. The evaluation based on the seedling's visual injury concluded that $11 \mathrm{DH}$ lines and $2 \mathrm{NRV}$ were tolerant, and $3 \mathrm{DH}$ lines and $2 \mathrm{NRV}$ were moderately tolerant.
\end{abstract}

Keywords: anther culture, evaluation, hydroponically, tolerance

\section{ABSTRAK}

Tantangan pemulia padi ke depan bertambah seiring dengan terjadinya perubahan iklim yang menyebabkan peningkatan salinitas lahan pertanian. Salinitas dapat mengakibatkan penurunan pertumbuhan dan kehilangan hasil yang besar dalam produksi padi. Tujuan penelitian ini ialah mengevaluasi toleransi salinitas galur-galur harapan padi sawah doubled-haploid /dihaploid (DH) hasil kultur antera pada fase bibit. Penelitian dilaksanakan di rumah kaca dari bulan Desember 2018 sampai Januari 2019. Penelitian dilakukan secara hidroponik dan disusun berdasarkan split plot rancangan kelompok lengkap teracak dengan empat ulangan. Petak utama ialah konsentrasi $\mathrm{NaCl}(0 \mathrm{mM}$ dan $120 \mathrm{mM}$ ) dan anak petak berupa genotipe padi yang terdiri atas 14 galur DH, 4 VUB, pembanding toleran (Pokkali), dan pembanding peka (Inpara 4). Evaluasi pertumbuhan bibit dan skoring kerusakan visual bibit dilakukan 14 hari sesudah pemberian NaCl. Hasil penelitian menunjukkan konsentrasi $\mathrm{NaCl} 120 \mathrm{mM}$ menyebabkan penurunan tinggi bibit, panjang akar, jumlah daun, jumlah anakan, bobot basah tajuk, bobot basah akar, bobot kering tajuk, bobot kering akar, bobot basah biomassa, dan bobot kering biomassa. Penurunan tinggi bibit dapat dipertimbangkan sebagai karakter penting dalam penapisan toleransi salinitas pada fase bibit. Hasil skoring terhadap kerusakan visual menghasilkan 11 galur DH dan 2 VUB toleran serta 3 galur DH dan 2 VUB moderat toleran.

Kata kunci: hidroponik, kultur antera, penapisan, toleransi

\section{PENDAHULUAN}

Perubahan iklim global berdampak langsung terhadap degradasi lahan, termasuk salinisasi lahan yang terjadi

\footnotetext{
* Penulis untuk korespondensi. e-mail: bspurwoko@apps.ipb. ac.id
}

meluas di lebih dari 100 negara, dan secara tidak langsung berdampak terhadap penurunan hasil pertanian (Hopmans et al., 2021) serta mengancam keberlanjutan pertanian di hampir semua negara, termasuk Indonesia (Karolinoerita dan Yusuf, 2020). Peningkatan permukaan air laut mendorong terjadinya intrusi air laut yang menyebabkan salinisasi lahan (Teh dan Koh, 2016), sehingga terbentuk lahan salin 
(Karolinoerita dan Yusuf, 2020), yaitu kondisi lahan yang memiliki daya hantar listrik /electrical conductivity (EC) tanah lebih dari $4 \mathrm{dSm}^{-1}$ (Singh et al., 2010). Masalah salinitas tanah menyebabkan rendahnya produktivitas lahan yang mengancam keamanan pangan (Wassmann et al., 2009) dan mengakibatkan sekitar 0.3-1.5 juta ha lahan pertanian tidak dapat berproduksi setiap tahunnya (Hopmans et al., 2021).

Tantangan salinitas di Indonesia akan semakin meningkat akibat intrusi air laut melalui peningkatan permukaan air laut karena perubahan iklim dan tsunami (Karolinoerita dan Yusuf, 2020). Permukaan air laut di Indonesia meningkat rata-rata $0.6 \mathrm{~cm} /$ tahun dan diprediksi dapat mencapai rata-rata setinggi $25-30 \mathrm{~cm}$ pada 2050 , sehingga dapat menyebabkan terjadinya penyusutan garis pantai Utara Jawa sampai $20 \mathrm{~km}$ pada 2100 (Bappenas, 2010). Sementara itu, lebih dari $25 \%$ penanaman padi di Pulau Jawa terletak dekat pantai atau dalam jangkauan 10 $\mathrm{km}$ dari pantai (Rumanti et al., 2018). Salinisasi lahan atau peningkatan salinitas lahan di daerah pesisir Utara Jawa (daerah Pantura) menjadi ancaman yang serius terhadap stabilitas produksi padi nasional karena daerah ini merupakan penyumbang utama produksi padi di Indonesia (Hairmansis et al., 2017). Meskipun belum tersedia data secara spasial terkait luas lahan dan sebaran lahan yang terpapar salinitas di Indonesia, potensi lahan nasional yang rentan terhadap peningkatan salinitas cukup luas, yaitu mencapai 12.02 juta ha (Karolinoerita dan Yusuf, 2020). Bappenas (2011) telah memproyeksikan kehilangan produksi padi dapat mencapai 2.7 juta ton sampai tahun 2050 akibat penyusutan lahan pertanaman padi serta meningkatnya salinitas pada lahanlahan yang berada di sepanjang garis pantai karena intrusi garam dari peningkatan permukaan air laut.

Cekaman salinitas berakibat negatif terhadap pertumbuhan dan produktivitas pada sebagian besar tanaman pertanian melalui pengaruh osmotik dan toksisitas ion pada proses fisiologis tanaman (Wassmann et al., 2009; Hopmans et al., 2021). Secara umum padi tergolong serealia yang sensitif terhadap cekaman salinitas (Reddy et al., 2017) dengan titik kritis sensitivitas terhadap salinitas adalah pada fase vegetatif awal dan reproduktif ( $\operatorname{Rad}$ et al., 2011). Perkecambahan benih dan pertumbuhan bibit padi dapat terhambat dalam kondisi cekaman salinitas (Kazemi dan Eskandari, 2011). Salinitas dengan EC $4 \mathrm{dSm}^{-1}, 8 \mathrm{dSm}^{-1}$, dan $12 \mathrm{dSm}^{-1}$ dapat menurunkan hasil padi secara signifikan masing-masing sebesar 31\%, 56\%, dan 71\% (Girma et al., 2017). Oleh karena itu, pengembangan varietas padi toleran salinitas perlu untuk terus dilakukan sebagai langkah antisipasi terhadap permasalahan salinitas di lahan-lahan potensial (Hairmansis dan Nafisah, 2020).

Karakter morfologi telah sering digunakan untuk kriteria penilaian toleransi terhadap salinitas pada padi. Evaluasi perubahan morfologi pada fase vegetatif dilakukan dengan memberikan perlakuan salinitas terhadap bibit tanaman padi, lalu dilakukan skoring terhadap kerusakan visual bibit berdasarkan Standard Evaluation System (SES) for rice dari IRRI (Egdane et al., 2003). Pengamatan tambahan dapat dilakukan terhadap tinggi bibit, panjang akar, bobot basah tajuk, dan lain-lain (Safitri et al., 2017; Kargbo et al., 2019; Farid et al., 2021). Galur-galur padi doubled-haploid (DH) hasil kultur antera berhasil diperoleh (Safitri et al., 2016) dan telah dilakukan serangkaian pengujian daya hasil pada beberapa lokasi (Hidayatullah et al., 2018). Perlu dilakukan konfirmasi toleransi terhadap salinitas pada galur-galur harapan padi DH yang dihasilkan, sehingga dapat dilepas menjadi varietas padi sawah yang memiliki keunggulan terkait toleransi terhadap salinitas. Varietas Inpari 13 dan Inpari 30 merupakan VUB yang digunakan sebagai pembanding dalam pengujian daya hasil di atas. Varietas Inpari 34 Salin Agritan dan Inpari 35 Salin Agritan merupakan VUB yang toleran salinitas pada fase bibit pada cekaman $12 \mathrm{dS} \cdot \mathrm{m}^{-1}$ (BB Padi, 2021). Penelitian ini bertujuan untuk mengevaluasi toleransi salinitas galurgalur harapan padi sawah doubled-haploid/dihaploid (DH) hasil kultur antera pada fase bibit.

\section{BAHAN DAN METODE}

Penelitian dilaksanakan di rumah kaca Balai Besar Penelitian dan Pengembangan Bioteknologi dan Sumber Daya Genetik Pertanian (BB Biogen), Bogor dari bulan Desember 2018 sampai Januari 2019 dan disusun berdasarkan split plot rancangan kelompok lengkap teracak dengan empat ulangan. Petak utama ialah konsentrasi $\mathrm{NaCl}$ ( $0 \mathrm{mM}$ dan $120 \mathrm{mM}$ ) dan anak petak ialah genotipe padi. Genotipe yang dievaluasi terdiri atas 14 galur harapan doubled-haploid/dihaploid (DH) padi sawah hasil kultur antera, empat varietas unggul baru (VUB), satu pembanding toleran salinitas (Pokkali), dan satu pembanding peka salinitas (Inpara 4) (Tabel 1). Satuan percobaan berupa empat bibit pada masing-masing perlakuan konsentrasi dan ulangan. Penelitian dilakukan pada fase bibit dengan metode Egdane et al. (2003) yang dimodifikasi, yaitu media hidroponik dengan larutan Yoshida yang mengandung $120 \mathrm{mM} \mathrm{NaCl}\left( \pm 13 \mathrm{dSm}^{-1}\right)$. Konsentrasi $120 \mathrm{mM} \mathrm{NaCl}$ dan pembanding peka salinitas (Inpara 4) yang digunakan mengacu pada hasil penelitian Safitri et al. (2017).

Bibit padi yang berumur tujuh hari setelah semai dari semua genotipe padi yang diuji dipindah tanam dari media semai ke media hidroponik. Bibit ini digulung dengan busa tipis, lalu diletakkan di lubang pada nampan styrofoam yang sudah dilubangi dan selanjutnya diapungkan pada media hidroponik Yoshida (17 L per bak). Aplikasi $\mathrm{NaCl}$ dilakukan 14 hari kemudian dan diberikan secara bertahap untuk menghindari osmotic shock. Aplikasi tahap pertama dengan menambahkan $60 \mathrm{mM} \mathrm{NaCl}$ dan dinaikkan menjadi $120 \mathrm{mM} \mathrm{NaCl}$ pada dua hari berikutnya. Penyesuaian $\mathrm{pH}$ (5.0-5.1) dilakukan dengan menambahkan $\mathrm{NaOH}$ dan $\mathrm{HCl}$ dua hari sekali. Penggantian media hidroponik dengan yang baru dilakukan seminggu sekali.

Skoring visual kerusakan bibit mengacu pada SES untuk padi dari IRRI (Egdane et al., 2003) (Tabel 2) dan dilakukan 14 hari setelah perlakuan $\mathrm{NaCl}$ atau saat pembanding peka Inpara 4 mati. Selanjutnya dilakukan pengamatan terhadap karakter pertumbuhan bibit pada tiga tanaman contoh dari masing-masing satuan percobaan. 
Tabel 1. Daftar genotipe padi yang digunakan dalam evaluasi toleransi terhadap salinitas

\begin{tabular}{llllll}
\hline No & Genotipe & Tetua (keterangan) & No & \multicolumn{1}{c}{ Genotipe } & Tetua (keterangan) \\
\hline 1 & HS1-5-1-1 & Inpara 5/IR77674 & 11 & HS17-3-1-3 & Dendang/Inpari 30 \\
2 & HS17-37-1-7 & Dendang/Inpari 30 & 12 & HS17-3-1-4 & Dendang/Inpari 30 \\
3 & HS17-3-1-1 & Dendang/Inpari 30 & 13 & HS15-13-1-1 & IR78788/Inpara 5 \\
4 & HS17-21-1-2 & Dendang/Inpari 30 & 14 & HS4-13-1-1 & IR77674/Inpari 29 \\
5 & HS4-13-1-4 & IR77674/Inpari 29 & 15 & Inpari 13 & Varietas unggul baru \\
6 & HS4-8-1-2 & IR77674/Inpari 29 & 16 & Inpari 30 & Varietas unggul baru \\
7 & HS4-13-1-3 & IR77674/Inpari 29 & 17 & Inpari 34 Salin Agritan & Varietas unggul baru \\
8 & HS17-31-1-1 & Dendang/Inpari 30 & 18 & Inpari 35 Salin Agritan & Varietas unggul baru \\
9 & HS2-9-1-1 & IR77674/Inpara 5 & 19 & Pokkali & Pembanding toleran \\
10 & HS4-17-1-1 & IR77674/Inpari 29 & 20 & Inpara 4 & Pembanding peka \\
\hline
\end{tabular}

Tabel 2. Standard Evaluation System (SES) dari IRRI untuk toleransi salinitas pada padi

\begin{tabular}{lll}
\hline Skor & \multicolumn{1}{c}{ Deskripsi gejala visual kerusakan bibit } & Kategori toleransi \\
\hline 1 & $\begin{array}{l}\text { Pertumbuhan normal, hanya beberapa daun tua yang menunjukkan gejala berwarna putih. } \\
\text { Tidak ada gejala terlihat pada daun-daun muda }\end{array}$ & Sangat toleran \\
3 & $\begin{array}{l}\text { Pertumbuhan hampir normal, ujung daun tua kering kecokelatan, beberapa daun tua sebagian } \\
\text { memutih }\end{array}$ & Toleran \\
5 & $\begin{array}{l}\text { Pertumbuhan terhambat, beberapa daun sudah mengering, titik tumbuh masih dapat tumbuh } \\
\text { dan memanjang }\end{array}$ & Moderat toleran \\
7 & $\begin{array}{l}\text { Pertumbuhan sepenuhnya berhenti, sebagian besar daun sudah kering, titik tumbuh sudah } \\
\text { mengering sehingga tidak dapat memanjang }\end{array}$ & Sangat peka \\
\hline
\end{tabular}

Sumber: Egdane et al. (2003)

Karakter pertumbuhan tersebut meliputi tinggi bibit, panjang akar, jumlah daun, jumlah anakan, bobot basah tajuk, bobot basah akar, bobot kering tajuk, bobot kering akar, bobot basah biomassa, dan bobot kering biomassa. Bobot biomassa dihitung dengan menjumlahkan bobot tajuk dan bobot akar. Pengamatan pada bobot kering dilakukan terhadap bibit yang telah dikeringovenkan pada suhu $80^{\circ} \mathrm{C}$ selama $3 \times 24$ jam. Penurunan pada semua karakter pertumbuhan dihitung berdasarkan selisih nilai karakter pada kondisi normal (0 $\mathrm{mM} \mathrm{NaCl})$ dengan nilai karakter pada kondisi salin (120 $\mathrm{mM} \mathrm{NaCl}$ ) dan dikali $100 \%$. Hasil pengamatan karakter pertumbuhan dianalisis ragam dan diuji lanjut DMRT pada taraf 5\% dengan aplikasi Statistical Tool for Agricultural Research (STAR). Selanjutnya dilakukan analisis korelasi Spearman dengan aplikasi Minitab 20 untuk karakter pertumbuhan dan penurunan karakter tersebut.

\section{HASIL DAN PEMBAHASAN}

Bibit pada perlakuan $0 \mathrm{mM} \mathrm{NaCl}$ menunjukkan kondisi visual yang normal, sedangkan pada perlakuan $120 \mathrm{mM} \mathrm{NaCl}$ ditemukan gangguan pertumbuhan berupa pengerdilan bibit (stunting) dan gejala kerusakan visual (Gambar 1). Gejala kerusakan visual yang ditemukan berupa ujung daun memutih, daun menggulung, dan daun kering kecokelatan. Kondisi kerusakan visual serupa pada padi yang mendapatkan cekaman salinitas juga dilaporkan pada hasil penelitian lain (Al-Amin et al., 2013; Mondal dan Borromeo, 2016; Eti et al., 2018), dengan genotipe toleran menunjukkan tanpa gejala kerusakan visual atau memiliki gejala kerusakan visual yang lebih ringan dibandingkan genotipe moderat dan genotipe peka. Berdasarkan evaluasi kerusakan bibit (Tabel 3), pembanding toleran Pokkali dan pembanding peka Inpara 4 memiliki skor masing-masing 3 dan 8.5. Selain kedua varietas pembanding, genotipe yang diuji masuk ke dalam dua kategori toleransi, yaitu toleran (skor 3-4) dan moderat toleran (skor 5-5.5). Dari 14 galur $\mathrm{DH}$, terdapat 11 galur kategori toleran dan 3 galur kategori moderat toleran. VUB yang diuji menunjukkan 2 varietas kategori toleran dan 2 varietas kategori moderat toleran.

Karakter tinggi bibit, panjang akar, jumlah daun, jumlah anakan, bobot basah tajuk, bobot basah akar, bobot kering tajuk, bobot kering akar, bobot basah biomassa, dan bobot kering biomassa merupakan karakter pertumbuhan yang sering diamati untuk mengevaluasi respon genotipe padi terhadap perlakuan cekaman salinitas (Ali et al., 2014; Mohammadi et al., 2014; Barua et al., 2015; Kargbo et al., 2019). Hasil analisis ragam dalam penelitian ini (Tabel 4) menunjukkan bahwa genotipe memiliki pengaruh sangat nyata terhadap semua karakter pertumbuhan tersebut. 

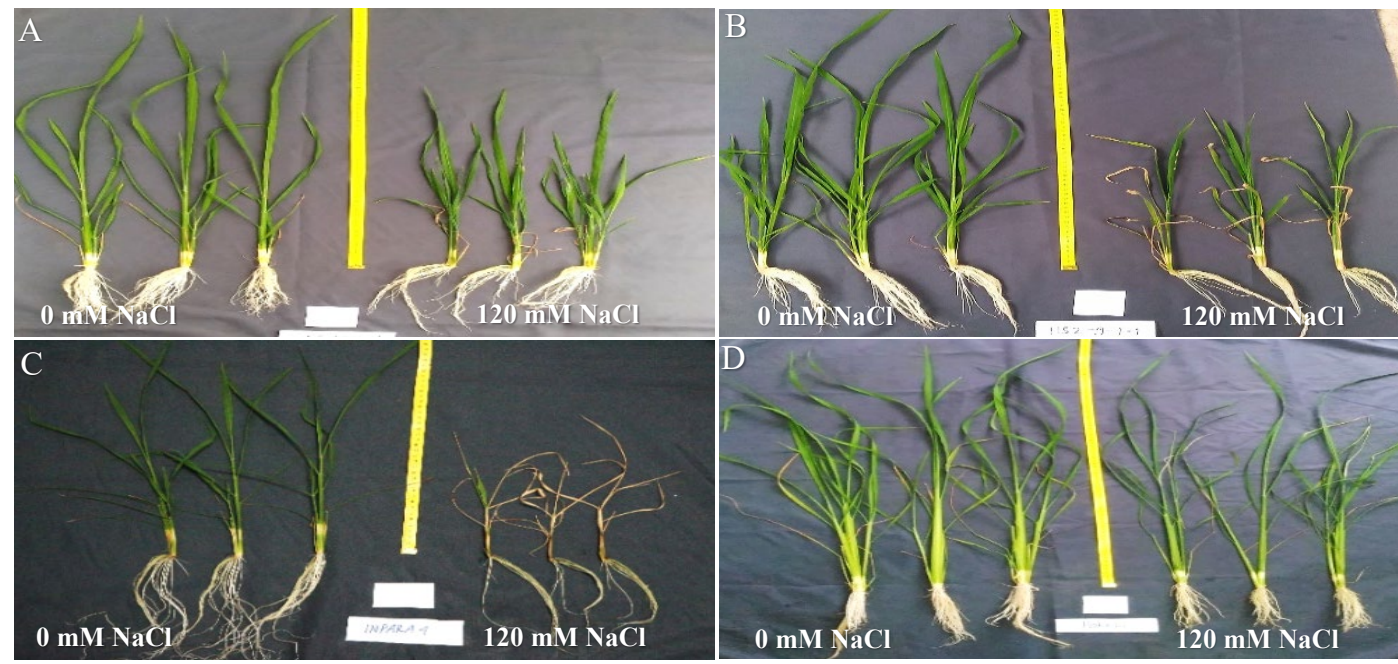

Gambar 1. Kondisi visual galur padi DH dan pembanding pada uji toleransi salinitas fase bibit: A. toleran (HS4-13-1-4), B. moderat toleran (HS2-9-1-1), C. pembanding peka (Inpara 4), dan D. pembanding toleran (Pokkali)

Konsentrasi berpengaruh nyata sampai sangat nyata pada hampir semua karakter kecuali pada panjang akar dan jumlah anakan, sedangkan sumber keragaman interaksi konsentrasi dan genotipe tidak berpengaruh nyata hanya pada jumlah anakan. Karakter pertumbuhan yang memiliki ragam interaksi berbeda nyata dapat digunakan sebagai dasar penentuan karakter seleksi (Anshori et al., 2021; Farid et al., 2021) karena karakter ini dapat menunjukkan adanya perbedaan respon genotipe ketika diberi cekaman salinitas.

Perlakuan salinitas $120 \mathrm{mM}$ menyebabkan penurunan pada semua karakter yang diamati. Selain hanya berdasarkan skoring kerusakan bibit, kombinasi skoring, karakter pertumbuhan pada kondisi salin, dan penurunan karakter pertumbuhan dapat digunakan dalam pendugaan genotipe toleran salinitas secara lebih efektif dan selektif (Anshori, 2018). Selain itu, hasil penelitian Anshori et al. (2021) mengindikasikan bahwa penurunan karakter pertumbuhan dari karakter pertumbuhan terseleksi (berdasarkan ragam interaksi yang nyata dan analisis korelasi) memiliki efektivitas yang lebih tinggi dalam pemodelan indeks toleransi salinitas dibandingkan karakter pertumbuhan terseleksi itu sendiri. Menurut Anshori (2018), penurunan karakter pertumbuhan pada genotipe yang dibandingkan dengan Pokkali juga dapat menjadi indikator tingkatan toleransi salinitas genotipe yang diuji dan validasi karakter seleksi. Oleh karena itu, evaluasi lebih lanjut terhadap penurunan karakter pertumbuhan juga dilakukan pada penelitian ini.

Respon penurunan tinggi bibit, panjang akar, jumlah daun, dan jumlah anakan terhadap salinitas disajikan pada Tabel 5. Sebanyak 9 dari 14 galur DH memiliki penurunan tinggi bibit yang lebih rendah dibandingkan penurunan galur DH (31.22\%) dan 2 galur di antaranya memiliki penurunan yang tidak berbeda nyata dibandingkan Pokkali (18.23\%). Hampir semua galur DH memiliki penurunan panjang akar yang lebih rendah dibandingkan Pokkali

Tabel 3. Hasil skoring gejala visual kerusakan bibit padi pada 14 hari setelah perlakuan $120 \mathrm{mM} \mathrm{NaCl}$ atau saat pembanding peka Inpara 4 mati

\begin{tabular}{llllclcc}
\hline No. & Genotipe & SES & Kategori & No. & \multicolumn{1}{c}{ Genotipe } & SES & Kategori \\
\hline 1 & HS1-5-1-1 & 3.5 & T & 11 & HS17-3-1-3 & 4.0 & T \\
2 & HS17-3-1-7 & 4.0 & T & 12 & HS17-3-1-4 & 5.0 & MT \\
3 & HS17-3-1-1 & 4.0 & T & 13 & HS15-13-1-1 & 4.0 & T \\
4 & HS17-21-1-2 & 5.0 & MT & 14 & HS4-13-1-1 & 3.0 & T \\
5 & HS4-13-1-4 & 3.5 & T & 15 & Inpari 13 & 5.0 & MT \\
6 & HS4-8-1-2 & 4.0 & T & 16 & Inpari 30 & 5.5 & MT \\
7 & HS4-13-1-3 & 4.0 & T & 17 & Inpari 34 Salin Agritan & 4.0 & T \\
8 & HS17-31-1-1 & 3.5 & T & 18 & Inpari 35 Salin Agritan & 3.5 & T \\
9 & HS2-9-1-1 & 5.5 & MT & 19 & Pokkali & 3.0 & T \\
10 & HS4-17-1-1 & 4.0 & T & 20 & Inpara 4 & 8.5 & SP \\
\hline
\end{tabular}

Keterangan: $\mathrm{SES}=$ skor kerusakan bibit; $\mathrm{T}=$ toleran; $\mathrm{MT}=$ moderat toleran; $\mathrm{SP}=$ sangat peka 
Tabel 4. Rekapitulasi sidik ragam karakter pertumbuhan yang diamati dalam evaluasi toleransi genotipe padi terhadap salinitas

\begin{tabular}{|c|c|c|c|c|c|c|c|c|c|c|c|}
\hline \multirow{2}{*}{$\begin{array}{l}\text { Sumber } \\
\text { keragaman }\end{array}$} & \multirow{2}{*}{$\mathrm{db}$} & \multicolumn{10}{|c|}{ Kuadrat tengah (KT) } \\
\hline & & TB & JD & JA & PA & $\mathrm{BBT}^{\mathrm{a}}$ & BKT & $\mathrm{BBA}$ & $\mathrm{BKA}^{\mathrm{b}}$ & $\mathrm{BBB}^{\mathrm{a}}$ & $\mathrm{BKB}$ \\
\hline Ulangan & 3 & $1,125.53 * *$ & $10.56 \mathrm{tn}$ & $2.52 \mathrm{tn}$ & $80.20 \mathrm{tn}$ & $0.17 \mathrm{tn}$ & $0.04 \mathrm{tn}$ & $2.81 \mathrm{tn}$ & $<0.01$ tn & $0.25^{*}$ & $0.01 \mathrm{tn}$ \\
\hline K & 1 & $13,628.46^{* *}$ & $196.54 * *$ & $2.23 \mathrm{tn}$ & $176.78 \mathrm{tn}$ & $1.57^{* *}$ & $2.35^{* *}$ & $6.55^{*}$ & $0.11^{* *}$ & $1.65^{* *}$ & $4.24 * *$ \\
\hline Galat (a) & 3 & 14.41 & 4.04 & 0.32 & 40.26 & 0.02 & 0.01 & 0.59 & $<0.01$ & 0.02 & 0.03 \\
\hline G & 19 & $437.75^{* *}$ & $26.32 * *$ & $1.62 * *$ & $62.08^{* *}$ & $0.07 * *$ & $0.13^{* *}$ & $0.38^{* *}$ & $<0.01 * *$ & $0.07 * *$ & $0.20 * *$ \\
\hline $\mathrm{K} \times \mathrm{G}$ & 19 & $19.19^{*}$ & $5.27 * *$ & 0.30 tn & $17.09 * *$ & $0.01 * *$ & $0.02 * *$ & $0.12 *$ & $<0.01 * *$ & $0.01 *$ & $0.03 * *$ \\
\hline Galat (b) & 114 & 9.82 & 2.64 & 0.18 & 3.85 & $<0.01$ & 0.01 & 0.064 & $<0.01$ & 0.01 & 0.01 \\
\hline Total & 159 & & & & & & & & & & \\
\hline KK (a) & & 7.59 & 18.23 & 43.00 & 34.59 & 66.10 & 22.48 & 105.00 & 58.99 & 72.30 & 29.46 \\
\hline KK (b) & & 6.22 & 14.67 & 32.42 & 10.69 & 23.10 & 19.02 & 34.80 & 23.48 & 24.67 & 19.34 \\
\hline
\end{tabular}

Keterangan: $\mathrm{K}=$ konsentrasi, $\mathrm{G}=$ genotipe, $\mathrm{TB}=$ tinggi bibit $(\mathrm{cm}), \mathrm{JD}=$ jumlah daun (helai), JA = jumlah anakan (batang), BBT \& BBA = bobot basah tajuk dan akar (g), BKT \& BKA = bobot basah tajuk dan akar $(\mathrm{g})$, BBB \& BKB = bobot basah dan kering biomassa $(\mathrm{g}), \mathrm{db}=$ derajat bebas, $*, * *$ berpengaruh nyata berdasarkan uji $\mathrm{F}$ pada $\alpha=5 \%$ dan $1 \%$, th $=$ tidak berpengaruh nyata, ${ }^{\mathrm{a}}=$ transformasi $\log (\mathrm{x}+1),{ }^{\mathrm{b}}=$ transformasi $\sqrt{ }(\mathrm{x}+0.5), \mathrm{KK}=$ koefisien keragaman

(38.44\%) dan hanya galur HS17-3-1-4 yang memiliki panjang akar tidak berbeda nyata dibandingkan Pokkali. Penurunan pada jumlah daun dan jumlah anakan sebagian besar galur DH tidak berbeda nyata dengan Pokkali. Galur HS17-3-1-7 menunjukkan penurunan pada jumlah daun dan jumlah anakan yang lebih rendah dibandingkan Pokkali serta galur HS4-13-1-4 lebih rendah dibandingkan Pokkali untuk penurunan jumlah daun. Hasil penelitian menunjukkan terdapat galur DH yang memiliki penurunan negatif pada panjang akar, jumlah daun, dan jumlah anakan. Penurunan negatif akibat perlakuan salinitas pada jumlah daun (Aliyu et al., 2016; Anshori, 2018), jumlah anakan (Anshori, 2018), dan panjang akar (Hussain et al., 2013; Zafar et al., 2015; Anshori, 2018) juga pernah dilaporkan sebelumnya. Penurunan negatif berarti terjadi peningkatan pada ketiga karakter tersebut setelah diberikan perlakuan salinitas. Menurut Aliyu et al. (2016), peningkatan jumlah daun dan jumlah anakan pada beberapa genotipe pada kondisi salin dimungkinkan karena adanya vigor tanaman dan kemampuan menghasilkan anakan atau disebabkan oleh suatu faktor yang masih belum diketahui dengan jelas yang memicu suatu mekanisme sehingga genotipe menjadi lebih vigor dengan adanya cekaman salinitas. Secara umum berdasarkan perbandingannya dengan Pokkali dan adanya penurunan negatif tersebut, galur DH pada penelitian ini menunjukkan panjang akar, jumlah daun, dan jumlah anakan yang relatif stabil dalam kondisi salin.

Padapenelitianini, Pokkali sebagai pembanding toleran salinitas memiliki penurunan tinggi bibit yang berbeda nyata lebih rendah dibandingkan pembanding peka salinitas (Inpara 4), tetapi tidak berbeda nyata dengan penurunan pada panjang akar, jumlah daun, dan jumlah anakan (Tabel 5). Hal ini menunjukkan bahwa genotipe toleran maupun genotipe peka sama-sama mengoptimalkan panjang akar, jumlah daun, dan jumlah anakan ketika tercekam salinitas. Penelitian ini menunjukkan bahwa penurunan tinggi bibit lebih ketat dalam menapis toleransi salinitas dibandingkan ketiga karakter lain, sehingga karakter ini berpotensi digunakan sebagai karakter seleksi.

Para peneliti telah melaporkan terjadinya penurunan genotipe padi pada karakter bobot basah tajuk, bobot basah akar, bobot kering tajuk, bobot kering akar (Chunthaburee et al., 2016; Safitri et al., 2017), bobot basah biomassa (Habib et al., 2016), dan bobot kering biomassa (Tahjib-Ul-Arif et al., 2018; Aala dan Gregorio, 2019) akibat cekaman salinitas. Respon penurunan pada bobot basah tajuk, bobot basah akar, bobot kering tajuk, bobot kering akar, bobot basah biomassa dan bobot kering biomassa setelah pemberian $120 \mathrm{mM} \mathrm{NaCl}$ pada penelitian ini ditunjukkan oleh Tabel 6. Secara umum, sebagian besar galur DH menunjukkan penurunan pada bobot basah tajuk, bobot basah akar, bobot kering tajuk, bobot kering akar, bobot basah biomassa, dan bobot kering biomassa yang tidak berbeda nyata dengan Pokkali (48.00\%, 46.51\%, 37.97\%, 48.37\%, 47.85\%, dan $40.22 \%$ untuk masing-masing penurunan karakter tersebut). Namun penurunan Pokkali pada ke enam karakter tersebut tidak berbeda nyata dengan Inpara 4. Galur yang memiliki penurunan lebih rendah dibandingkan Pokkali yaitu HS4-131-4 untuk penurunan pada bobot basah tajuk, bobot kering tajuk, bobot basah biomassa, dan bobot kering biomassa serta HS1-5-1-1 untuk penurunan pada bobot basah akar, bobot kering akar, dan bobot basah biomassa.

Respon penurunan karakter pertumbuhan semua VUB menunjukkan pola yang sama, kecuali untuk penurunan pada tinggi bibit dan panjang akar (Tabel 5 dan Tabel 6). Masingmasing VUB memiliki penurunan jumlah daun, jumlah anakan, bobot basah tajuk, bobot basah akar, bobot kering tajuk, bobot kering akar, bobot basah bimassa, dan bobot kering biomassa yang setara dengan Pokkali dan dengan VUB yang lain. Sementara itu, penurunan tinggi bibit semua VUB lebih tinggi dibandingkan Pokkali, dengan varietas Inpari 35 Salin Agritan menunjukkan penurunan yang lebih 
Tabel 5. Penurunan tinggi bibit, panjang akar, jumlah daun, dan jumlah anakan pada genotipe padi setelah perlakuan 120 $\mathrm{mM} \mathrm{NaCl}$

\begin{tabular}{|c|c|c|c|c|}
\hline \multirow{2}{*}{ Genotipe } & \multicolumn{4}{|c|}{ Penurunan karakter pertumbuhan (\%) } \\
\hline & Tinggi bibit & Panjang akar & Jumlah daun & Jumlah anakan \\
\hline HS1-5-1-1 & 30.18 bcde & -5.82 cdefg & $1.3 \mathrm{~cd}$ & $-18.8 \mathrm{abc}$ \\
\hline HS17-3-1-7 & $30.66 \mathrm{bcde}$ & $14.80 \mathrm{bcd}$ & $-8.4 d$ & $-83.3 c$ \\
\hline HS17-3-1-1 & $30.46 \mathrm{bcde}$ & $12.96 \mathrm{bcde}$ & $4.1 \mathrm{bcd}$ & $0.0 \mathrm{ab}$ \\
\hline HS17-21-1-2 & $30.57 \mathrm{bcde}$ & $12.89 \mathrm{bcde}$ & $28.0 \mathrm{ab}$ & $27.1 \mathrm{ab}$ \\
\hline HS4-13-1-4 & $28.85 \mathrm{cdef}$ & $-7.85 \mathrm{defg}$ & $-9.1 d$ & $-27.8 b c$ \\
\hline HS4-8-1-2 & $26.37 \mathrm{efg}$ & $-11.42 \mathrm{fg}$ & $23.0 \mathrm{abc}$ & $52.8 \mathrm{ab}$ \\
\hline HS4-13-1-3 & 35.59abcde & $-14.04 \mathrm{~g}$ & $4.2 \mathrm{bcd}$ & $16.7 \mathrm{ab}$ \\
\hline HS17-31-1-1 & $20.90 \mathrm{fg}$ & $-10.03 \mathrm{efg}$ & $16.0 \mathrm{abcd}$ & $18.8 \mathrm{ab}$ \\
\hline HS2-9-1-1 & $38.58 \mathrm{ab}$ & $-4.53 \mathrm{cdefg}$ & $19.7 \mathrm{abc}$ & $-2.1 a b$ \\
\hline HS4-17-1-1 & $36.41 \mathrm{abcd}$ & $4.38 \mathrm{bcdefg}$ & $23.5 \mathrm{abc}$ & $21.3 \mathrm{ab}$ \\
\hline HS17-3-1-3 & $32.51 \mathrm{bcde}$ & $11.58 \mathrm{bcde}$ & $25.0 \mathrm{abc}$ & $35.8 \mathrm{ab}$ \\
\hline HS17-3-1-4 & 30.91 bcde & $19.48 \mathrm{ab}$ & $24.8 \mathrm{abc}$ & $32.9 \mathrm{ab}$ \\
\hline HS15-13-1-1 & $37.47 \mathrm{abc}$ & $11.18 \mathrm{bcdef}$ & $10.4 \mathrm{abcd}$ & $7.1 \mathrm{ab}$ \\
\hline HS4-13-1-1 & $27.56 \mathrm{def}$ & $4.45 \mathrm{bcdefg}$ & 11.0abcd & $-27.5 b c$ \\
\hline Inpari 13 & $37.70 \mathrm{abc}$ & $16.93 \mathrm{abc}$ & $21.3 \mathrm{abc}$ & $10.8 \mathrm{ab}$ \\
\hline Inpari 30 & $37.67 \mathrm{abc}$ & $9.56 \mathrm{bcdef}$ & $36.3 \mathrm{a}$ & $26.8 \mathrm{ab}$ \\
\hline Inpari 34 Salin Agritan & 30.31 bcde & $11.15 \mathrm{bcdef}$ & $17.3 \mathrm{abc}$ & $8.5 \mathrm{ab}$ \\
\hline Inpari 35 Salin Agritan & $27.27 \mathrm{def}$ & $21.44 \mathrm{ab}$ & $24.2 \mathrm{abc}$ & $16.7 \mathrm{ab}$ \\
\hline Pokkali & $18.23 \mathrm{~g}$ & $38.44 \mathrm{a}$ & $23.8 \mathrm{abc}$ & $38.3 \mathrm{ab}$ \\
\hline Inpara 4 & $41.98 \mathrm{a}$ & $21.97 \mathrm{ab}$ & $27.8 \mathrm{abc}$ & $55.2 \mathrm{a}$ \\
\hline Rata-rata galur DH & 31.22 & 2.72 & 12.4 & 3.8 \\
\hline
\end{tabular}

Keterangan: Angka yang diikuti huruf yang sama pada kolom yang sama tidak berbeda nyata berdasarkan uji DMRT pada $\alpha=5 \%$

rendah dibandingkan Inpari 13 dan Inpari 30, tetapi tidak berbeda nyata dengan Inpari 34 Salin Agritan. Penurunan panjang akar Inpari 13 dan Inpari 35 Salin Agritan tidak berbeda nyata dengan Pokkali, sedangkan Inpari 30 dan Inpari 34 Salin Agritan lebih rendah dibandingkan Pokkali.

Koefisien korelasi Spearman menunjukkan skor kerusakan bibit berkorelasi negatif sangat nyata $(r \geq-0.64$; $\mathrm{p}<0.01)$ dengan karakter tinggi bibit, bobot basah tajuk, bobot basah akar, bobot kering tajuk, bobot kering akar, bobot basah biomassa, dan bobot kering biomassa pada kondisi salin (Tabel 7). Meskipun demikian, nilai korelasi yang tinggi dan sangat nyata terhadap skor kerusakan bibit pada penurunan karakter pertumbuhan hanya ditunjukkan oleh penurunan pada tinggi bibit $(\mathrm{r}=0.83 ; \mathrm{p}<0.01)$, disusul oleh penurunan pada bobot kering tajuk (0.64), bobot basah tajuk (0.63), bobot kering biomassa (0.61), dan bobot basah biomassa (0.58) (Tabel 8). Korelasi yang sangat nyata pada penurunan bobot basah biomassa ini lebih dipengaruhi oleh penurunan bobot basah tajuk karena penurunan bobot basah akar memiliki korelasi yang tidak nyata terhadap skor kerusakan bibit. Penurunan tinggi bibit dinilai dapat menggambarkan toleransi salinitas seperti analisis skoring (Anshori, 2018), maka karakter pertumbuhan yang berhubungan erat dengan penurunan tinggi bibit menjadi penting untuk diketahui. Karakter yang memiliki korelasi positif nyata $(\mathrm{p}<0.05)$ dengan penurunan tinggi bibit adalah penurunan pada bobot basah tajuk (0.50), bobot kering tajuk (0.56), dan bobot kering biomassa (0.52) (Tabel 8).

Berdasarkan beberapa analisis di atas, karakter yang berhubungan dengan tajuk lebih dapat mencirikan toleransi salinitas pada fase bibit dibandingkan karakter terkait akar. Hal ini sejalan dengan berbagai hasil penelitian (Ali et al., 2014; Nayyeripasand et al., 2019; Anshori et al., 2021; Yadav et al., 2021). Selain itu, hasil analisis menunjukkan bahwa penurunan tinggi bibit dapat direkomendasikan sebagai karakter seleksi dalam penapisan genotipe padi terhadap salinitas pada fase bibit. Meskipun tidak seketat penurunan tinggi bibit dalam menapis salinitas, penurunan pada bobot basah tajuk, bobot kering tajuk, dan bobot kering biomassa juga dapat dipertimbangkan sebagai karakter seleksi berdasarkan analisis di atas. Penggunaan karakter penurunan bobot basah tajuk (Anshori et al., 2021) atau penurunan pada bobot basah tajuk, bobot kering tajuk, dan bobot kering biomassa (Anshori, 2018) dalam proses seleksi genotipe padi toleran salinitas pernah dilaporkan sebelumnya. 
Tabel 6. Penurunan bobot basah tajuk dan akar, bobot kering tajuk dan akar serta bobot basah dan bobot kering biomassa pada genotipe padi setelah perlakuan $120 \mathrm{mM} \mathrm{NaCl}$

\begin{tabular}{|c|c|c|c|c|c|c|}
\hline \multirow{2}{*}{ Genotipe } & \multicolumn{6}{|c|}{ Penurunan karakter pertumbuhan (\%) } \\
\hline & $\mathrm{BBT}^{\mathrm{a}}$ & $\mathrm{BBA}$ & BKT & $\mathrm{BKA}^{\mathrm{b}}$ & $\mathrm{BBB}^{\mathrm{a}}$ & BKB \\
\hline HS1-5-1-1 & $27.93 \mathrm{bc}$ & $-7.22 \mathrm{~d}$ & $18.21 \mathrm{de}$ & $22.85 \mathrm{~d}$ & $21.97 \mathrm{~d}$ & $19.41 \mathrm{~cd}$ \\
\hline HS17-3-1-7 & $28.63 b c$ & $27.27 \mathrm{abcd}$ & $27.22 \mathrm{cde}$ & 42.76abcd & $28.48 \mathrm{~cd}$ & $30.91 \mathrm{bcd}$ \\
\hline HS17-3-1-1 & $39.06 \mathrm{abc}$ & $31.59 \mathrm{abc}$ & $30.30 \mathrm{bcde}$ & $46.25 \mathrm{abcd}$ & 37.49abcd & $33.97 \mathrm{abcd}$ \\
\hline HS17-21-1-2 & $57.00 \mathrm{a}$ & $63.53 \mathrm{a}$ & $52.87 \mathrm{ab}$ & $65.73 \mathrm{a}$ & $58.37 \mathrm{a}$ & $55.64 \mathrm{ab}$ \\
\hline HS4-13-1-4 & $18.77 \mathrm{c}$ & $16.06 \mathrm{~cd}$ & $13.30 \mathrm{e}$ & $28.11 \mathrm{~cd}$ & $18.57 \mathrm{~d}$ & $16.66 \mathrm{~d}$ \\
\hline HS4-8-1-2 & $44.86 \mathrm{ab}$ & $36.32 \mathrm{abc}$ & 39.39abcd & $51.79 \mathrm{abc}$ & 43.11abcd & $42.05 \mathrm{abc}$ \\
\hline HS4-13-1-3 & $43.92 \mathrm{ab}$ & 26.96abcd & $36.76 \mathrm{abcd}$ & 42.66abcd & 40.84abcd & $38.07 \mathrm{abcd}$ \\
\hline HS17-31-1-1 & $28.83 b c$ & $37.81 \mathrm{abc}$ & $29.77 \mathrm{bcde}$ & $37.45 \mathrm{bcd}$ & $30.83 \mathrm{bcd}$ & $31.52 \mathrm{bcd}$ \\
\hline HS2-9-1-1 & $47.36 \mathrm{ab}$ & $15.73 \mathrm{~cd}$ & $41.45 \mathrm{abcd}$ & 39.34abcd & 42.06abcd & $41.14 \mathrm{abc}$ \\
\hline HS4-17-1-1 & $44.77 \mathrm{ab}$ & $22.36 \mathrm{bcd}$ & $46.71 \mathrm{abc}$ & $56.33 \mathrm{ab}$ & $41.02 \mathrm{abcd}$ & $49.04 \mathrm{ab}$ \\
\hline HS17-3-1-3 & $57.78 \mathrm{a}$ & $43.29 \mathrm{abc}$ & $52.12 \mathrm{abc}$ & $53.90 \mathrm{abc}$ & $54.94 \mathrm{ab}$ & $52.90 \mathrm{ab}$ \\
\hline HS17-3-1-4 & $55.70 \mathrm{a}$ & $59.32 \mathrm{ab}$ & $49.60 \mathrm{abc}$ & $62.28 \mathrm{ab}$ & $56.75 \mathrm{ab}$ & $52.80 \mathrm{ab}$ \\
\hline HS15-13-1-1 & $52.42 \mathrm{ab}$ & $51.06 \mathrm{abc}$ & $51.91 \mathrm{abc}$ & $59.04 \mathrm{ab}$ & $52.19 \mathrm{abc}$ & $53.42 \mathrm{ab}$ \\
\hline HS4-13-1-1 & $43.66 \mathrm{ab}$ & $31.71 \mathrm{abc}$ & $38.72 \mathrm{abcd}$ & $51.48 \mathrm{abc}$ & $41.54 \mathrm{abcd}$ & $41.28 \mathrm{abc}$ \\
\hline Inpari 13 & $54.31 \mathrm{a}$ & $48.39 \mathrm{abc}$ & $45.92 \mathrm{abc}$ & $54.81 \mathrm{abc}$ & $53.27 \mathrm{abc}$ & $47.75 \mathrm{ab}$ \\
\hline Inpari 30 & $62.72 \mathrm{a}$ & $48.71 \mathrm{abc}$ & $56.00 \mathrm{a}$ & $62.87 \mathrm{ab}$ & $60.08 \mathrm{a}$ & $57.55 \mathrm{a}$ \\
\hline Inpari 34 Salin Agritan & $44.66 \mathrm{ab}$ & $40.97 \mathrm{abc}$ & 39.36abcd & $53.10 \mathrm{abc}$ & 44.07abcd & $42.80 \mathrm{abc}$ \\
\hline Inpari 35 Salin Agritan & $53.97 \mathrm{a}$ & $48.88 \mathrm{abc}$ & 42.09abcd & $53.34 \mathrm{abc}$ & $53.02 \mathrm{abc}$ & $44.44 \mathrm{ab}$ \\
\hline Pokkali & $48.00 \mathrm{ab}$ & $46.51 \mathrm{abc}$ & 37.97abcd & 48.37abcd & $47.85 \mathrm{abc}$ & $40.22 \mathrm{abcd}$ \\
\hline Inpara 4 & $60.62 \mathrm{a}$ & $35.72 \mathrm{abc}$ & $51.54 \mathrm{abc}$ & $55.24 \mathrm{abc}$ & $56.53 \mathrm{ab}$ & $52.23 \mathrm{ab}$ \\
\hline Rata-rata galur DH & 42.19 & 32.56 & 37.70 & 49.05 & 40.58 & 39.88 \\
\hline
\end{tabular}

Keterangan: BBT - BBA - BBB = bobot basah tajuk - akar - biomassa, BKT - BKA - BKB = bobot kering tajuk - akar - biomassa, ${ }^{\text {a }},{ }^{\mathrm{b}}=$ data dianalisis dengan transformasi $\log (x+1)$ dan transformasi $\sqrt{ }(x+0.5)$; angka yang diikuti huruf yang sama pada kolom yang sama tidak berbeda nyata berdasarkan uji DMRT pada $\alpha=5 \%$

Tabel 7. Koefisien korelasi Spearman antar karakter pertumbuhan dan skor kerusakan bibit pada genotipe padi pada perlakuan $120 \mathrm{mM} \mathrm{NaCl}$

\begin{tabular}{|c|c|c|c|c|c|c|c|c|c|c|}
\hline Variabel & SES & $\mathrm{TB}$ & PA & JD & $\mathrm{JA}$ & BBT & BBA & BKT & BKA & BBB \\
\hline TB & $-0.64 * *$ & & & & & & & & & \\
\hline PA & -0.01 & -0.05 & & & & & & & & \\
\hline JD & $-0.47 *$ & 0.12 & 0.16 & & & & & & & \\
\hline $\mathrm{JA}$ & -0.44 & 0.03 & 0.14 & 0.93 & & & & & & \\
\hline BBT & $-0.84 * *$ & $0.73 * *$ & 0.02 & $0.58 * *$ & $0.51^{*}$ & & & & & \\
\hline $\mathrm{BBA}$ & $-0.73^{* *}$ & $0.62 * *$ & 0.12 & $0.58 * *$ & $0.57 * *$ & $0.89 * *$ & & & & \\
\hline BKT & $-0.87 * *$ & $0.67 * *$ & 0.04 & $0.56^{*}$ & $0.46^{*}$ & $0.93 * *$ & $0.88 * *$ & & & \\
\hline BKA & $-0.81 * *$ & $0.71 * *$ & 0.22 & $0.50 *$ & 0,42 & $0.88 * *$ & $0.89 * *$ & $0.92 * *$ & & \\
\hline BBB & $-0.83^{* *}$ & $0.72 * *$ & 0.09 & $0.57^{*}$ & $0.50 *$ & $0.99 * *$ & $0.93 * *$ & $0.94 * *$ & $0.92 * *$ & \\
\hline $\mathrm{BKB}$ & $-0.87 * *$ & $0.65^{* *}$ & 0.04 & $0.57 * *$ & $0.46^{*}$ & $0.93 * *$ & $0.88^{* *}$ & $0.99 * *$ & $0.92 * *$ & $0.94 * *$ \\
\hline
\end{tabular}

Keterangan: $\mathrm{SES}=$ skor kerusakan bibit; $\mathrm{TB}=$ tinggi bibit; $\mathrm{PA}=$ panjang akar; JD = jumlah daun; JA = jumlah anakan; $\mathrm{BBT}=$ bobot basah tajuk; $\mathrm{BBA}=$ bobot basah akar; $\mathrm{BKT}=$ bobot kering tajuk; $\mathrm{BKA}=$ bobot kering akar; $\mathrm{BBB}=$ bobot basah biomassa; $\mathrm{BKB}=$ bobot kering biomassa 
Tabel 8. Koefisien korelasi Spearman antar penurunan karakter pertumbuhan dan skor kerusakan bibit pada evaluasi toleransi genotipe padi terhadap salinitas

\begin{tabular}{|c|c|c|c|c|c|c|c|c|c|c|}
\hline Variabel & SES & $\mathrm{X} 1$ & $\mathrm{X} 2$ & $\mathrm{X} 3$ & $\mathrm{X} 4$ & $\mathrm{X} 5$ & $\mathrm{X} 6$ & $\mathrm{X7}$ & $\mathrm{X} 8$ & X9 \\
\hline $\mathrm{X} 1$ & $0.83 * *$ & & & & & & & & & \\
\hline $\mathrm{X} 2$ & 0.19 & 0.13 & & & & & & & & \\
\hline X3 & $0.49 *$ & 0.25 & 0.43 & & & & & & & \\
\hline $\mathrm{X} 4$ & 0.32 & 0.05 & 0.27 & $0.82 * *$ & & & & & & \\
\hline $\mathrm{X} 5$ & $0.63 * *$ & $0.50 *$ & $0.52 *$ & $0.91 * *$ & $0.71 * *$ & & & & & \\
\hline X6 & 0.21 & -0.01 & $0.54 *$ & $0.63 * *$ & $0.50 *$ & $0.70 * *$ & & & & \\
\hline$X 7$ & $0.64 * *$ & $0.56^{*}$ & 0.35 & $0.84 * *$ & $0.59 * *$ & $0.93 * *$ & $0.67 * *$ & & & \\
\hline X8 & $0.55^{*}$ & 0.43 & $0.47 *$ & $0.76^{* *}$ & $0.55^{*}$ & $0.83 * *$ & $0.76^{* *}$ & $0.91 * *$ & & \\
\hline X9 & $0.58 * *$ & 0.39 & $0.54 *$ & $0.89 * *$ & $0.66 * *$ & $0.97 * *$ & $0.81 * *$ & $0.91 * *$ & $0.87^{* *}$ & \\
\hline X10 & $0.61 * *$ & $0.52 *$ & 0.36 & $0.82 * *$ & $0.58 * *$ & $0.91 * *$ & $0.72 * *$ & $0.99 * *$ & $0.95^{* *}$ & $0.91 * *$ \\
\hline
\end{tabular}

Keterangan: SES = skor kerusakan bibit, penurunan pada karakter: $\mathrm{X} 1=$ tinggi bibit; $\mathrm{X} 2$ = panjang akar; X3 = jumlah daun; X4 = jumlah anakan; X5 = bobot basah tajuk; X6 = bobot basah akar; X7 = bobot kering tajuk; X8 = bobot kering akar; X9 = bobot basah biomassa; X10 = bobot kering biomassa

\section{KESIMPULAN}

Salinitas $\left(120 \mathrm{mM} \mathrm{NaCl} / \mathrm{EC}= \pm 13 \mathrm{dS} \cdot \mathrm{m}^{-1}\right)$ dapat mengakibatkan kerusakan pada bibit padi dan menyebabkan respon penurunan pada tinggi bibit, panjang akar, jumlah daun, jumlah anakan, bobot basah tajuk dan akar, bobot kering tajuk dan akar serta bobot basah dan kering biomassa. Penurunan tinggi bibit dapat dipertimbangkan sebagai karakter penting dalam pengujian toleransi padi terhadap salinitas pada fase bibit. Skoring visual berdasarkan gejala kerusakan bibit menghasilkan 11 galur DH kategori toleran dan 3 galur DH kategori moderat toleran.

\section{UCAPAN TERIMA KASIH}

Terima kasih disampaikan kepada BB Biogen, Badan Penelitian dan Pengembangan Pertanian, Kementerian Pertanian yang telah menyediakan fasilitas untuk pengujian ini.

\section{DAFTAR PUSTAKA}

Aala, W.F., G.B. Gregorio. 2019. Morphological and molecular characterization of novel salt-tolerant rice germplasms from the Philippines and Bangladesh. Rice Sci. 26:178-188. Doi:10.1016/ j.rsci.2018.09.001.

Al-Amin, M., M.M. Islam, S.N. Begum, M.S. Alam, M. Moniruzzaman, M.A.K. Patwary. 2013. Evaluation of rice germplasm under salt stress at the seedling stage through SSR markers. Int. J. Agric. Res. Innov. Technol. 3:52-59. Doi:10.3329/ijarit.v3i1.16093.
Ali, M.N., L. Yeasmin, S. Gantait, R. Goswami, S. Chakraborty. 2014. Screening of rice landraces for salinity tolerance at seedling stage through morphological and molecular markers. Physiol. Mol. Biol. Plants. 20:411-423. Doi:10.1007/s12298-0140250-6.

Aliyu, R.E., K. Adamu, S.K. Sakariyahu. 2016. Phenotypic response of Oryza species seedlings to saline conditions. AJEA. 12:1-11. Doi:10.9734/ AJEA/2016/26703.

Anshori, M.F. 2018. Karakterisasi dan seleksi galur-galur padi (Oryza sativa L.) dihaploid adaptif cekaman salinitas. Tesis. Sekolah Pascasarjana. Institut Pertanian Bogor. Bogor.

Anshori, M.F., B.S. Purwoko, I.S. Dewi, S.W. Ardie, W.B. Suwarno. 2021. A New approach to select doubled haploid rice lines under salinity stress using indirect selection index. Rice Sci. 28:368-378. Doi:10.1016/ j.rsci.2021.05.007.

[Bappenas] Badan Perencanaan Pembangunan Nasional. 2010. Scientific basis: analysis and projection of sea level rise and extreme weather events. https://www. bappenas.go.id [25 Juli 2021].

[Bappenas] Badan Perencanaan Pembangunan Nasional. 2011. Indonesia adaptation strategy: improving capacity to adapt. https://www.bappenas.go.id [25 Juli 2021]. 
[BB Padi] Balai Besar Penelitian Tanaman Padi. 2021. Deskripsi varietas unggul padi. https://bbpadi.litbang. pertanian.go.id [6 Oktober 2021].

Barua, R., M. De Ocampo, J. Egdane,A.M. Ismail, S. Mondal. 2015. Phenotyping rice (Oryza sativa L.) genotypes for physiological traits associated with tolerance of salinity at seedling stage. Sci. Agric. 12:156-162. Doi:10.15192/pscp.sa.2015.12.3.156162.

Chunthaburee, S., A. Dongsansuk, J. Sanitchon, W. Pattanagul, P. Theerakulpisut. 2016. Physiological and biochemical parameters for evaluation and clustering of rice cultivars differing in salt tolerance at seedling stage. Saudi J. Biol. Sci. 23:467-477. Doi:10.1016/j.sjbs.2015.05.013.

Egdane, J.A., N.A. Vispo, R. Mohammadi, J. Amas, M.L. Katimbang, J.D. Platten, A. Ismail, G.B. Gregorio. 2003. Phenotyping Protocols for Salinity and Other Problem Soils. International Rice Research Institute, Los Banos, $\mathrm{PH}$.

Eti, I., M. Rasel, L. Hassan, A. Ferdausi. 2018. Morphological based screening and genetic diversity analysis of the local rice (Oryza sativa L.) landrace at the seedling stage for salinity tolerance. J. Biosci. Agric. Res. 18:1496-1511.

Farid, M., Nasaruddin, M.F. Anshori, Y. Musa, H. Iswoyo, A.I. Sakinah. 2021. Interaction of rice salinity screening in germination and seedling phase through selection index based on principal components. Chil. J. Agric. Res. 81:368-377. Doi:10.4067/S071858392021000300368 .

Girma, B.T., H.M. Ali, A.A. Gebeyaneh. 2017. Effect of salinity on final growth stage of different rice (Oryza sativa L.) Genotypes. Asian J. Agric. Res. 11:1-9.

Habib, N., M.S. Akram, M.T. Javed, M. Azeem, Q. Ali, H.L. Shaheen, M. Ashraf. 2016. Nitric oxide regulated improvement in growth and yield of rice plants grown under salinity stress: antioxidant defense system. Appl. Ecol. Environ. Res. 14:91-105. Doi: http://dx.doi.org/10.15666/aeer/1405_091105.

Hairmansis, A., Nafisah, A. Jamil. 2017. Towards developing salinity tolerant rice adaptable for coastal regions in Indonesia. p. 72-79. In M. Muhaemin, Y. Hidayat, H.A.W. Lengkey (Eds.). 2nd International Conference on Sustainable Agriculture and Food Security: A Comprehensive Approach. Sumedang 12-13 Oktober 2015.

Hairmansis, A., Nafisah. 2020. Pengembangan varietas unggul padi untuk lahan terdampak salinitas. Pangan. 29:161-170.
Hidayatullah, A., B.S. Purwoko, I.S. Dewi, W.B. Suwarno. 2018. Agronomic performance and yield of doubled haploid rice lines in advanced yield trial. Sabrao J. Breed. Genet. 50:242-253.

Hopmans, J.W., A.S. Qureshi, I. Kisekka, R. Munns, S.R. Grattan, P. Rengasamy, A. Ben-Gal, S. Assouline, M. Javaux, P.S. Minhas, P.A.C. Raats, T.H. Skaggs, G. Wang, Q. De Jong van Lier, H. Jiao, R.S. Lavado, N. Lazarovitch, B. Li, E. Taleisnik. 2021. Critical knowledge gaps and research priorities in global soil salinity. p. 1-191. In D. Sparks (Ed.). Advances in Agronomy. v. 169. Academic Press, San Diego, US.

Hussain, M., H. Park, M. Farooq, K. Jabran, D. Lee. 2013. Morphological and physiological basis of salt resistance in different rice genotypes. Int. J. Agric. Biol. 15:113-118.

Kargbo, S.S., F.A. Showemimo, J.B.O. Porbeni, P.O. Akintokun. 2019. Response of rice genotypes to salinity under hydroponic conditions. Agro-Science. 18:11-18. Doi:10.4314/as.v18i3.3.

Karolinoerita, V., W.A. Yusuf. 2020. Salinisasi lahan dan permasalahannya di Indonesia. Jurnal Sumberdaya Lahan. 14:91-99. Doi:http://dx.doi.org/10.21082/ jsdl.v14n2.2020.91-99.

Kazemi, K., H. Eskandari. 2011. Effects of salt stress on germination and early seedling growth of rice (Oryza sativa) cultivars in Iran. African J. Biotechnol. 10:17789-17792. Doi:10.5897/AJB11.2219.

Mohammadi, R., M.S. Mendioro, G.Q. Diaz, G.B. Gregorio, R.K. Singh. 2014. Genetic analysis of salt tolerance at seedling and reproductive stages in rice (Oryza sativa). Plant Breed. 133:548-559. Doi:10.1111/ pbr. 12210.

Mondal, S., T.H. Borromeo. 2016. Screening of salinity tolerance of rice at early seedling stage. J. Biosci. Agric. Res. 10:843-847. Doi:10.18801/ jbar.100116.102.

Nayyeripasand, L., G.A. Garosi, A. Ahmadikhah. 2019. Selection for salinity tolerance in an international rice collection at vegetative stage. AJCS. 13:837846. Doi:10.21475/ajcs.19.13.06.p1327.

Rad, H.E., F. Aref, M. Rezaei, E. Amiri, M.R. Khaledian. 2011. The effects of salinity at different growth stage on rice yield. Ecol. Environ. Conserv. 17:455-462.

Reddy, I.N.B.L., B.K. Kim, I.S. Yoon, K.H. Kim, T.R. Kwon. 2017. Salt tolerance in rice: focus on mechanisms and approaches. Rice Sci. 24:123-144. Doi:10.1016/ j.rsci.2016.09.004. 
Rumanti, I.A., A. Hairmansis, Y. Nugraha, Nafisah, U. Susanto, P. Wardana, R.E. Subandiono, Z. Zaini, H. Sembiring, N.I. Khan, R.K. Singh, D.E. Johnson, A.M. Stuart, Y. Kato. 2018. Development of tolerant rice varieties for stress-prone ecosystems in the coastal deltas of Indonesia. F. Crop. Res. 223:75-82. Doi:10.1016/j.fcr.2018.04.006.

Safitri, H., B.S. Purwoko, I.S. Dewi, S.W. Ardie. 2016. Kultur antera untuk mendapatkan galur padi toleran salinitas. J. Agron. Indonesia 44:221-227. Doi:10.24831/jai.v44i3.12770.

Safitri, H., B.S. Purwoko, I.S. Dewi, S.W. Ardie. 2017. Salinity tolerance of several rice genotypes at seedling stage. Indones. J. Agric. Sci. 18:63-68.

Singh, R.K., E. Redona, L. Refuerzo. 2010. Varietal improvement for abiotic stress tolerance in crop plants: special reference to salinity in rice. p. 387415. In A. Pareek, S.K. Sopory, H.J. Bohnert, Govindjee (Eds.). Abiotic Stress Adaptation in Plants: Physiological, Molecular and Genomic Foundation. Springer Netherlands, Heidelberg, DE.

Tahjib-Ul-Arif, M., M.A. Sayed, M.M. Islam, M.N. Siddiqui, S.N. Begum, M.A. Hossain. 2018. Screening of rice landraces (Oryza sativa L.) for seedling stage salinity tolerance using morpho-physiological and molecular markers. Acta Physiol. Plant. 40:1-12. Doi:10.1007/ s11738-018-2645-4.

Teh, S.Y., H.L. Koh. 2016. Climate change and soil salinization: impact on agriculture, water and food security. IJAFP. 2:1-9.

Wassmann, R., S.V.K. Jagadish, S. Heuer, A. Ismail, E. Redona, R. Serraj, R.K. Singh, G. Howell, H. Pathak, K. Sumfleth. 2009. Climate change affecting rice production: the physiological and agronomic basis for possible adaptation strategies. p. 59-122. In D. Sparks (Ed.). Advances in Agronomy. v. 101. Academic Press, San Diego, US.

Yadav, A.K., A. Kumar, N. Grover, R.K. Ellur, H. Bollinedi, S.G. Krishnan, P.K. Bhowmick, K.K. Vinod, M. Nagarajan, A.K. Singh. 2021. Genome-wide association study reveals marker-trait associations for early vegetative stage salinity tolerance in rice. 10:559. Doi:10.3390/plants10030559.

Zafar, S.A., S. Shokat, H.G.M. Ahmed, A. Khan, M.Z. Ali, R.M. Atif. 2015. Assessment of salinity tolerance in rice using seedling based morpho-physiological indices. Adv. Life Sci. 2:142-149. 